\section{交献}

1) H. Weisz : Mikrochim. Acta, 1954, 140.

2) H. Weisz : "Microanalysis by the Ring Oven Technique" (1961), (Pergamon Press, London).

3) A. Musil, W. Haas, J. Drabner : Mikrochim. Acta, 1962, 1121.

4) F. R. Haba, C. L. Wilson : Mikrochim. Ichnoanal. Acta, 1963, 196 ; Chem. Abstr., 58, 11956 (1963).

5) S. D. Biswas, K. N. Munshi, A. K. Dey : Mikrochim. Ichnoanal. Acta, 1963, 40 ; Chem. Abstr., 58, 8395 (1963).

6) M. B. Celap, T. J. Janjic, M. Ilic : Mikrochim. Acta, 1962, 504.

7) A. F. Farr, A. L. Chaney : Anal. Chem., 33, 1790 (1961).

8) P. V. Penrifoy, M. Nager : ibid., 32, 1135 (1960).

9) T. Meisel, A. Nemeth, L. Erdey : Mikrochim. Acta, 1961, 874.

10) C. Huygen : Mikrochim. Ichnoanal. Acta, 1963, 6 ; Chem. Abstr., 58, 10656 (1963).

11) H. Ballczo, M. Hodos : Mikrochim. Acta, 1960, 267.

12) A. Biro : Magyar Kém Folyóirat., 66, 285 (1960) ; Chem. Abstr., 54, 3042 (1960).

13) H. Ballczo, H. Weisz : Mikrochim. Acta,
1957, 751 .

14) J.B. Mooney : Anal. Chem., 34, 1506 (1962).

15) H. Weisz, L. J. Ottendorfer: Mikrochim. Acta, 1961, 191.

16) H. Weisz, L. J. Ottendorfer : ibid., 1962, 725.

17) H. Mallisa, F. Loley : Anal. Chim. Acta, 27, 381 (1962).

18) D. A. Hilton, D. Reed : Analyst, 89, 132 (1964).

19) H. Weisz : Talanta, 11, 1041 (1964).

$$
\text { is }
$$

Microdetermination of nickel in nickel-bearing alloys with dimethylglyoxime by the ring oven technique. Yai ShIobara (Department of Chemistry, Faculty of Science, Tokyo Kyoiku University, Bunkyo-ku, Tokyo)

The Weisz's ring oven techniques has been applied to the separation, concentration and determination of nickel in several nickel-bearing alloys. The method is rapid, taking about 10 min. to complete an analysis. The average relative error of the method is 1 to $3 \%$ when applied to the determination of nickel in Armsbronze, copper-nickel alloys and German silver. As little as 10 to $20 \mu \mathrm{g}$ of samples are sufficient for the rapid determination of nickel. The method may also find its use in other fields.

(Received Jan. 19, 1965)

\title{
沈殿分離-チオシアン酸アンモニウムによる 鉄鋼中の微量ニオブの光度定量
}

\author{
蔭山 良一，遠藤 芳秀，東森 利安*
}

\footnotetext{
鉄鋼中の微量二オブ定量法として，EDTA で鉄その他の共存元素を陰ぺいし，ベリリウムをコレク ターとしてアンモニアアルカリ性でニオブを沈殿分離し，分離したニオブをチオシアン酸アンモニウム 吸光光度法で定量した。

EDTA-ベリリウム分離法でニオブを分離するとき，他元素の陰ぺいに用いる EDTA の過剩量のな いときは，二オブははとんど定量的に分離できるが，試料中にチタンが共存する場合，チタンもニオブ と同様沈殿するので，チタンの共沈を扣さえるためやや過剩の EDTA を加える必要がある.この場 合, EDTA の過剰量に比例して二オブの収率はわずかながら減少し，10\% EDTA 溶液 $3 \mathrm{ml}$ の過剩 でチタン約 $5 \mathrm{mg}$ を陰ぺいできるが、ニオブの回収率は約 $95 \%$ となる.

この分離法の利点はニオブの分離の際，チオシアン酸アンモニウムと着色錯体を生成するモリブデン， タングステン，チタンなどを可溶性錯塩とするてとができるので，てれらの元素が共存しても二オブの 定量になんら影響を与えず，特にニオブを含有する特殊鋼に有効である。
} 
1 はしがき

鉄鋼中のニオブ定量法としては種々な方法があるが， その代表的なものは JIS（1963）に採用されているタン ニン分離ーピロガロール法であろう.

この方法はニオブ量が比較的多い場合には好結果が得 られるが，0.1\% 以下のときはタンニンによる分離は定 量的でなく，またニオブの呈色郕であるピロガロールも 微量のニオブを対象とした場合, 若干感度不足である.

鉄鋼中の微量ニオブを対象とした分離法には，Kid$\operatorname{man}^{1)}$ のフェニルアルゾン酸分離法 あるいはフッ化物 抽出法2などがあり，いずれも好結果が得られるようで あるが，特殊鋼を対象とした場合はモリブデン，タング ステン，チタンなどの妨害を受けやすく，これらを含を 鋼種については，これらの方法を直接適用することがで きないようである.

著者らは，鉄鋼中の微量ニオブの分離法として， EDTA で鉄（III）その他の共存元素を陰ぺいし，ベリ リウムをコレクターとしてアンモニアアルカリ性で微量 ニオブを共沈する分離法を試みたところ，陰ぺいに用い る EDTA 過剩量が汴一定であれば，二オブの回収率 もまた定量的であることがわかった。

したがって，本分離操作における 基礎的条件を確立 し，分離したニオブをチオシアン酸アンモニウム吸光光 度法で定量したところ，好結果が得られた。

以下，実験の経過它報告する.

\section{2 試薬および装置}

（1）二オブ標準溶液 A：三津和化学製の金属ニオブ (99.6\%) を硫酸水素カリウムで融解し， $1.2 M$ 酒石酸 溶液でうすめて $20 \mu \mathrm{g} \mathrm{Nb} / \mathrm{m} l, 5 \mu \mathrm{g} \mathrm{Nb} / \mathrm{m} l$ の溶液を 調製した。

（2）二オブ標準溶液 B : 上記（1）の金属ニオブを 硝酸, フッ化水素酸で溶解し, 硫酸を加え硫酸白煙発生 処理を行なったのち，水でうすめて $200 \mu \mathrm{g} \mathrm{Nb} / \mathrm{m} l$ 打 よび $50 \mu \mathrm{g} \mathrm{Nb} / \mathrm{m} l$ の溶液を調製した.

（3）ベリリウム溶液：硫酸ベリリウムを水汇溶解し $\tau, 5 \mathrm{mg} \mathrm{Be} / \mathrm{ml}$ の溶液を調製した.

(4) $10 \%$ EDTA 溶液 : EDTA-2Na $2 \mathrm{H}_{2} \mathrm{O} 100 \mathrm{~g}$ を水溶解して $1 l$ にした。

(5) $2 M$ 塩化第一スズ溶液 : 塩化第一スズ $\left(\mathrm{SnCl}_{2}\right.$. $\left.2 \mathrm{H}_{2} \mathrm{O}\right) 112.8 \mathrm{~g}$ を塩酸に溶解し,塩酸でうすめて $250 \mathrm{ml}$ にした.

（6） $1.2 M$ 酒石酸溶液， $3 M$ チオシアン酸アンモ二 ウム溶液, アセトン, そのほかの試薬はすべて特級品を 用い，水はイオン交換脱塩水を用いた。

（7）光電光度計：日立製 $\mathrm{FPW}-4$ 型，フィルター $\mathrm{S} 37$, 吸収セル $10 \mathrm{~mm}$.

（8） $\mathrm{pH} \times$-タ一：東亜電波製 HM-5 型.
3 分析操作

試料 $1 \mathrm{~g}$ (ニオブ含量が $0.2 \%$ 以上のときは，ニオブ 含量が $2 \mathrm{mg}$ 以下になるよう適宜採取する) を $300 \mathrm{ml}$ ビーカーにはかりとり, 王水 $20 \mathrm{ml}$ を加えて加熱溶解 し, 過塩素酸 $20 \mathrm{ml}$ を加え, 引き続き加熱して過塩素酸 の白煙を発生させながら液量が約 $10 \mathrm{ml}$ になるまで濃縮 する（試料中にクロムを $50 \mathrm{mg}$ 以上含んでいるときは， 過塩素酸白煙発生時に塩化ナトリウムを用いて塩化ク口 ミルとして揮散させる). 冷却後, 塩酸 $10 \mathrm{ml}$ を加えて 塩を溶解し, ベリリウム溶液 $(5 \mathrm{mg} \mathrm{Be} / \mathrm{ml}) 2 \mathrm{~m} l$, $10 \%$ EDTA 溶液(EDTA と錯塩を生成する共存元素の 当量十約 $3 \mathrm{~m} l)$ を加え，水でうすめて液量を約 $130 \mathrm{ml}$ にする. アンモニア水を加えて約 $\mathrm{pH} 3$ に調節し, 約 2 分間煮沸したのち, アンモニア水 $15 \mathrm{~m} l$ を加えてベリ リウム，ニオブの水酸化物沈殿を生成させ，2〜3 分間 煮沸後, 流水中で泠却して約 30 分間放置する. 沈殿を 口過し, アンモニア水 $(2+100)$ で 6〜7 回洗浄し, さ らに水で 2 回洗浄する．沈殿は口紙とともに白金るつぼ に移し入れ，約 $550^{\circ} \mathrm{C}$ で灰化したのち，硫酸 $(1+1)$ $0.5 \mathrm{~m} l$, フッ化水素酸 $5 \mathrm{~m} l$ を加光, 加熱して 硫酸白 煙を発生させる． $1.2 M$ 酒石酸溶液を加えて塩を溶解 し, $50 \mathrm{~m} l \times$ メフラスコに移し入れ, $1.2 M$ 酒石酸溶液 でうすめて正確に $50 \mathrm{~m} l$ にする. この溶液 $5 \mathrm{~m} l$ を正確 に $50 \mathrm{~m} l$ メスフラスコに分取し（ニオブ含量が $0.03 \%$ 以下のときは $10 \mathrm{~m} l$ 分取する), $1.2 M$ 酒石酸溶液 $5 \mathrm{~m} l$, 塩酸 $10 \mathrm{~m} l, 2 M$ 塩化第一スズ溶液 $1 \mathrm{~m} l$, 水 $5 \mathrm{~m} l$, ア セトン $10 \mathrm{~m} l$ をこの順序でそれぞれ正確に加兑, 約 $20^{\circ} \mathrm{C}$ に冷却する. 次に $3 M$ チオシアン酸アンモ二ウム溶液 $10 \mathrm{ml}$ を正確に加え, $1.2 M$ 酒石酸溶液でうすめて正確 に $50 \mathrm{ml}$ にし, よく振り混ぜたのち約 $20^{\circ} \mathrm{C}$ に保ちな がら 20 分間放置し，すみやかに波長 $385 \mathrm{~m} \mu$ における 吹光度を水を対比液として測定（吸収セル $10 \mathrm{~mm}$ ）し， あらかじめ作成してある検量線よりニオブ量を求める.

\section{4 実験および考察}

Cheng ${ }^{3)}$ は金属とほぼ当量の EDTA が共存してい る場合の各金属水酸化物沈殿生成と $\mathrm{pH}$ の関係沉ついて 実験し, pH 6.5〜10 の領域で沈殿する元素はベリリウ ム, 二オブ, タンタル, チタン, 水銀, 銀, スズ, アン チモンなどであると表示している.

したがって，鉄鋼中のニオブの分離に EDTA を院ぺ い戍に用いれば，大部分の鉄（III）は EDTA 錯塩と なり，そのほか鉄鋼中に含まれるほとえどの元素も同じ く可溶性塩となり分離できるものと推察される. 
しかし本実験では微量ニオブの定量を対象としている ため，単独でニオブのみを水酸化物として分離すること は困難であることが予想されるので，ニオブ 沈殿生成 時, コレクターとして, 前川らの報告4)（EDTA 共存 下，スズの沈殿生成にコレクターとしてベリリウムを用 いている）を参照し，この実験でもべリリウムを用いる ことにした.

また分離後のニオブの定量には, Levitt, Freund ら5)の行なったニオブに対して比較的高感度なチオシア ン酸アンモニウムを用いて光度定量することにした.

\section{$4 \cdot 1$ ベリリゥムをコレクターとしてのニオブの分離}

ベリリウムをコレクターとした場合のニオブの共沈効 果および EDTA の影響について調べるため, ニオブ標 準溶液 $\mathrm{B} の 一$ 定量をとり, ベリリウム溶液 $2 \mathrm{ml}$ ( $\mathrm{Be} \fallingdotseq$ $10 \mathrm{mg}$ ）および 10\% EDTA 溶液の種々の量ならびに 塩酸 $10 \mathrm{ml}$, 過塩素酸 $10 \mathrm{ml}$ を加えたのち, 水でうすめ て液量を䄪 $130 \mathrm{ml}$ にし, アンモニア水で中和後, さら にその過剩 $10 \mathrm{ml}$ を加えてベリリウムおよびニオブを沈 殿させ, 約 3 分間煮沸後, 3 の操作に準じてニオブを分 離し， $1 / 10$ に分液後, チオシアン酸アンモニウムでニ オブを定量した場合と, 分離操作を行なわずに二オブを 直接呈色させた場合と比較して回収率を求めた。

その結果, Table I に示すように EDTA が共存し ない場合のニオブはほとんど回収されるが，EDTA の 共存量が増加するにしたがって回収率はわずかながら低 下する.これは EDTA の過剩により, Nb-EDTA の 見かけの安定度が増加し, 沈殿生成を阻害するものと考 えられる.しかし EDTA の過剩量がほぼ一定であれ ば, ニオブの回収率もほとんど一定であった.

次にニオブ標準溶液Bの種々の量をとり,10\% EDTA 溶液 $3.5 \mathrm{ml}$ を共存させ, ニオブを分離定量した結果, Table II に示すように二オブ量が $200 \mu \mathrm{g}$ 以下のよう

Table I Relation between recoveries of niobium and excess amount of EDTA

\begin{tabular}{|c|c|c|c|c|c|}
\hline \multirow{2}{*}{$\begin{array}{l}10 \% \text { EDTA } \\
\text { added } \\
(\mathrm{m} l)\end{array}$} & \multirow{2}{*}{$\begin{array}{c}\mathrm{Nb} \\
\text { added } \\
(\mu \mathrm{g})\end{array}$} & \multicolumn{2}{|c|}{$\mathrm{Nb}$ found $(\mu \mathrm{g})$} & \multicolumn{2}{|c|}{ Recovery (\%) } \\
\hline & & (1) & $(2)$ & (1) & (2) \\
\hline 0 & 400 & 380 & 385 & 95.0 & 96.3 \\
\hline 2.5 & "I & 375 & 380 & 93.8 & 95.0 \\
\hline 3.5 & "I & 380 & 380 & 95.0 & 95.0 \\
\hline 4.5 & " & 375 & 370 & 93.8 & 92.5 \\
\hline 5.5 & "I & 370 & 380 & 92.5 & 95.0 \\
\hline 10.0 & "I & 355 & 345 & 88.8 & 86.3 \\
\hline 15.0 & "I & 330 & 320 & 82.5 & 80.0 \\
\hline
\end{tabular}

Filter : S37, Cell width : $10 \mathrm{~mm}$
Table II Recoveries of various amounts of $\mathrm{Nb}$ from EDTA solution

\begin{tabular}{|c|c|c|c|c|c|}
\hline \multirow{2}{*}{$\begin{array}{c}\mathrm{Nb} \\
\text { added } \\
(\mu \mathrm{g})\end{array}$} & \multirow{2}{*}{$\begin{array}{c}10 \% \text { EDT A } \\
\text { added } \\
(\mathrm{ml} l)\end{array}$} & \multicolumn{2}{|c|}{$\mathrm{Nb}$ found $(\mu \mathrm{g})$} & \multicolumn{2}{|c|}{ Recovery (\%) } \\
\hline & & (1) & (2) & (1) & (2) \\
\hline 100 & 3.5 & 90 & 94 & 90.0 & 94.0 \\
\hline 200 & " & 180 & 180 & 90.0 & 90.0 \\
\hline 300 & 11 & 285 & 285 & 95.0 & 95.0 \\
\hline 400 & " & 385 & 375 & 96.3 & 93.8 \\
\hline 800 & " & 755 & 740 & 94.4 & 92.5 \\
\hline 1200 & " & 1155 & 1140 & 96.3 & 95.0 \\
\hline 1600 & " & 1503 & 1503 & 93.9 & 93.9 \\
\hline 2000 & " & 1910 & 1885 & 95.5 & 94.3 \\
\hline
\end{tabular}

Filter : S37, Cell width : $10 \mathrm{~mm}$

な場合の収率はわずかながら低くなる傾向があるが，そ れ以上のものは約 95\% の収率でほぼ一定の回収率が得 られた。

したがって，実際試料適用の場合は分離操作を経た検 量線を用いる必要がある.

また過剩の EDTA 共存の際, 水酸化ベリリウムの沈 殿を煮沸生成させる場合，EDTA の過剩により沈殿を 消失することがあった．これは煮沸時 Be-EDTA の見 かけの安定度が増加し, 溶解度が増大したものと考光ら れる・しかしこのような場合でも，煮沸後冷却すればふ たたび沈殿を生成し，10\% EDTA 溶液 $3.5 \mathrm{ml}$ 過剩の 場合, 煮沸時間は 5 分まで, 沈殿生成時の泠却温度 $1 E 〜$ $30^{\circ} \mathrm{C}$ および冷却放置時間 30〜90 分の範囲ではニオブ の回収はほとんど変わらなかった。

\section{$4 \cdot 2$ 共存元素の影響}

4.2.1 鉄 鉄の影響を調べるため, 電解鉄 $1 \mathrm{~g}$ およ びニオブ標準溶液 $\mathrm{B}$ の種々の量をはかりとり，3の操作 に従って (10\% EDTA 溶液 $70 \mathrm{ml}$ を添加した. この場 合の EDTA 過剩量は約 $3.5 \mathrm{~m} l$ になる) ニオブを分離

Table III Influence of $\mathrm{Fe}^{3+}$ on recoveries of $\mathrm{Nb}$

\begin{tabular}{|c|c|c|c|c|c|}
\hline \multirow{2}{*}{$\begin{array}{l}\mathrm{Fe}^{3+} \\
\text { added } \\
(\mathrm{g})\end{array}$} & \multirow{2}{*}{$\begin{array}{c}\mathrm{Nb} \\
\text { added } \\
(\mu \mathrm{g})\end{array}$} & \multicolumn{2}{|c|}{$\mathrm{Nb}$ found $(\mu \mathrm{g})$} & \multicolumn{2}{|c|}{ Recovery (\%) } \\
\hline & & (1) & (2) & (1) & (2) \\
\hline 1.0 & 50 & 45 & 45 & 90.0 & 90.0 \\
\hline$"$ & 100 & 90 & 95 & 90.0 & 95.0 \\
\hline$" \prime$ & 200 & 180 & 185 & 90.0 & 92.5 \\
\hline " & 300 & 285 & 290 & 95.0 & 96.7 \\
\hline "I & 400 & 385 & 380 & 96.3 & 95.0 \\
\hline$" \prime$ & 800 & 760 & 750 & 95.0 & 93.8 \\
\hline "I & 1200 & 1130 & 1130 & 94.2 & 94.2 \\
\hline " & 1600 & 1520 & 1510 & 95.0 & 95.0 \\
\hline "I & 2000 & 1890 & 1890 & 94.5 & 94.5 \\
\hline
\end{tabular}

Each solution contained $10 \%$ EDTA $70 \mathrm{ml}$, Filter : S37, Cell width : $10 \mathrm{~mm}$ 
定量した結果, 鉄（III）は EDTA によって陰ぺいさ れ，鉄を含まない場合 (Table II) と同率のニオブ回 収率が得られ, 鉄 $1 \mathrm{~g}$ の共存もなんら影響のないことが わかった. その結果を Table III に示す.

4.2.2 チタン EDTA-ベリリウムでニオブを分離 するとき，同時に沈殿してチオシアン酸アンモニウムで 呈色し，ニオブの定量に影響する元素にチタンがある. チタンは EDTA の過剩が共存しないときは定量的に沈 殿するが，EDTA の過剩共存により，Ti-EDTA の見 かけの安定度を高くし, EDTA により陰ぺいされると 考えらる. 3 の操作で分離操作を行なったのちニオブを 定量した場合は，Table IV に示すように, 10\% EDTA 溶液過剩量約 $3.5 \mathrm{ml}$ の共存で約 $8 \mathrm{mg}$ のチタンを十分 陰ペいできる.

Table IV Masking of Ti with EDTA on separation of $\mathrm{Nb}$

\begin{tabular}{ccccc}
\hline $\begin{array}{c}\text { Ti added } \\
(\mathrm{mg})\end{array}$ & $\begin{array}{c}\text { Fe added } \\
(\mathrm{g})\end{array}$ & $\begin{array}{c}\mathrm{Nb} \text { added } \\
(\mu \mathrm{g})\end{array}$ & \multicolumn{2}{c}{$\begin{array}{c}\mathrm{Nb} \text { found }(\mu \mathrm{g}) \\
(1)\end{array}$} \\
\hline 0 & 1.0 & 400 & 390 & $(2)$ \\
2 & $\prime \prime$ & $\prime \prime$ & 390 & 385 \\
4 & $\prime \prime$ & $\prime \prime$ & 382 & 394 \\
6 & $\prime \prime$ & $\prime \prime$ & 385 & 399 \\
8 & $\prime \prime$ & $\prime \prime$ & 402 & 385 \\
10 & $\prime \prime$ & $\prime \prime$ & 461 & 423 \\
\hline
\end{tabular}

Each solution contained 10\% EDTA $70 \mathrm{ml}$, Filter : S37, Cell width : $10 \mathrm{~mm}$

$4 \cdot 2 \cdot 3$ モリブテン，タングステン，コバルト＼cjkstart本分 離法では，これらの元素はアンモニアあるいは EDTA と可溶性錯塩を生成して沈殿しないが，水酸化ベリリウ ムの沈殿に随伴したとき，チオシアン酸アンモニウムと 呈色錯体をつくるので，その影響について調べた結果， 少なくともモりブデン，コバルトはそれぞれ $50 \mathrm{mg}$, タ

Table V Influence of Mo, Co, W on the proposed method

\begin{tabular}{rcccccc}
\hline \hline $\begin{array}{c}\text { Fe } \\
(\mathrm{mg})\end{array}$ & $\begin{array}{c}\text { Co } \\
(\mathrm{mg})\end{array}$ & $\begin{array}{c}\mathrm{Mo} \\
(\mathrm{mg})\end{array}$ & $\begin{array}{c}\text { W } \\
(\mathrm{mg})\end{array}$ & $\begin{array}{c}\mathrm{Nb} \\
(\mu \mathrm{g})\end{array}$ & $\begin{array}{c}\text { Nb } \\
\text { found }\end{array}$ & $\begin{array}{c}\text { Excess } \\
\text { amount of } \\
10 \% \text { EDTA } \\
(\mathrm{m} l)\end{array}$ \\
\hline 1000 & 0 & 0 & 0 & 400 & 391 & 3.3 \\
970 & 30 & $\prime \prime$ & $\prime \prime$ & $\prime \prime$ & 385 & 4.7 \\
950 & 50 & $\prime \prime$ & $\prime \prime$ & $\prime \prime$ & 380 & 5.7 \\
970 & 0 & 30 & $\prime \prime$ & $\prime \prime$ & 390 & 3.4 \\
950 & $\prime \prime$ & 50 & $\prime \prime$ & $" \prime$ & 391 & 3.5 \\
995 & $\prime \prime$ & 0 & 5 & $\prime \prime$ & 390 & 3.5 \\
990 & $\prime \prime$ & $\prime \prime$ & 10 & $\prime \prime$ & 391 & 3.8 \\
\hline
\end{tabular}

Each solution contained 10\% EDTA $70 \mathrm{~m} l$, Filter : S37, Cell width : $10 \mathrm{~mm}$
ングステンは $10 \mathrm{mg}$ 共存してもニオブの定量に影響し ない. その結果を Table V に示す.

4.2.4 クロム クロムは3の操作では過塩素酸でク ロム（VI）に酸化され，理論的にはEDTA と反応しな いが，水酸化ベリリウムでニオブを沈殿させるとき煮沸 操作を行なうので，クロム（VI） は溶液中の EDTA で 一部還元されてクロム（III）を生成する，このクロム (III) は EDTA の錯塩生成速度が小さいので, アンモ 二ア水で急激に $\mathrm{pH}$ を上昇させたとき, 水酸化クロムを 生ずる場合があり，この沈殿があると口過速度を小さく し，作業能率上好ましくないので，試料中にクロムが大 量に共存するようなときは，クロムをクロム（VI） と し，塩化ナトリウムを添加して塩化クロミルとして揮散 させるほうがよい.

しかし，この揮散法は若干操作が繁雑になるので，ク ロム含量の低い場合には，還元されたクロム（III）を Cr-EDTA 錯塩として, 水酸化クロムの沈殿生成を抑 制することもできる.

Table VI は, クロム（VI）をEDTA 共存下 $\mathrm{pH}$ 3 で加熱し， EDTA で還元されたクロム（III）をCrEDTA としてクロムを陰ペいする方法により，少なく ともクロム $50 \mathrm{mg}$ が共存しても影響のないことを示し ている。したがって低クロムの試料については，pH 3 で Cr-EDTA の錯塩生成操作を加えれば，しいて塩化 クロミルの揮散操作を行なう必要はない。

Table VI Influence of $\mathrm{Cr}$ on the proposed method

\begin{tabular}{|c|c|c|c|c|c|}
\hline \multicolumn{3}{|c|}{ Added } & \multicolumn{2}{|c|}{$\begin{array}{c}\text { Nb found } \\
(\mu \mathrm{g})\end{array}$} & \multirow{2}{*}{$\begin{array}{l}\text { Excess } \\
\text { amount of } \\
10 \% \text { EDT A } \\
(\mathrm{ml})\end{array}$} \\
\hline $\begin{array}{c}\mathrm{Fe} \\
(\mathrm{mg})\end{array}$ & $\begin{array}{c}\mathrm{Cr} \\
(\mathrm{mg})\end{array}$ & $\begin{array}{l}\mathrm{Nb} \\
(\mu \mathrm{g})\end{array}$ & (1) & $(2)$ & \\
\hline 1000 & 0 & 400 & 392 & 394 & 3.3 \\
\hline 990 & 10 & $" \prime$ & 394 & 394 & 4.0 \\
\hline 970 & 30 & $" 1$ & 394 & 388 & 5.3 \\
\hline 950 & 50 & $" 1$ & 390 & 399 & 6.6 \\
\hline
\end{tabular}

Each solution contained $10 \%$ EDTA $70 \mathrm{ml}$,

Filter : S37, Cell width : $10 \mathrm{~mm}$

4.2.5 共存元素吾と EDTA 添加韋との関係 本定 量法では，クロム（VI），シリコンは EDTA と結合せ ずまたモリブデン，タングステンのように原子量の大 きい元素が共存する場合は EDTA 添加量を適宜変える 必要がある.しかし以上の実験結果より，試料中にこれ らの元素およびコバルトが 合量で $50 \mathrm{mg}$ 以下共存する 場合は, $10 \%$ EDTA 溶液添加量はひょう取試料全体を 鉄 としてその当量+約 $3 \mathrm{ml}$ でよい.この場合， $10 \%$ EDTA 過剩量は約 $3 \sim 5 \mathrm{ml}$ の範囲にある. 
$4 \cdot 3$ チオシアン酸アンモニウムによるニオブ 呈色条 件の検討

本実験は微量のニオブの定量を対象にしているので, 高感度の呈色法が必要であるため, Levitt, Freund ${ }^{5)}$ が発表したアセトンー水系溶液でニオブをチオシアン 錯 塩として呈色する方法を用いた.

Levitt, Freund はニオブ呈色時の試薬濃度の影響に ついて, 塩酸, チオシアン酸アンモニウム, アセトンの 濃度が高くなるほど，また塩化第一スズの濃度が高くな るほど, ニオブの色調は増加し, 酒石酸, 硫酸水素カリ ウム注ニオブの色調を弱めると報告しており，ニオブー チオシアン錯塩を安定させる適当な試薬濃度はないよう であるので, 著者らも 3 の操作に示したように, 原報ら どおりの呈色条件を用いた。

しかしニオブ呈色後, 時間の経過とともに漸次増色す る傾向があるので, ニオブ標準溶液Aを用いて直接呈色 させ, ニオブ呈色後の経時変化および温度の影響につい て調べた.

その結果, 経時変化については Fig. 1 に示すように わずかではあるが漸次増色し, 同一放置時間での空試験 值を補正すれ泟一定の吸光度を示す。

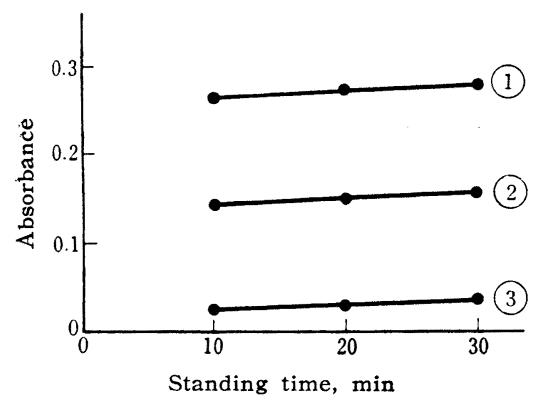

Fig. 1 Effect of standing time on absorbance (1) $\mathrm{Nb}(80 \mu \mathrm{g} / 50 \mathrm{ml})$ (2) $\mathrm{Nb}(40 \mu \mathrm{g} / 50 \mathrm{~m} l)$ (3) $\mathrm{Nb}(0 \mu \mathrm{g} / 50 \mathrm{~m} l)$
またニオブ呈色時の温度の影響については, Fig. 2 に 示すように，少なくとも $18 \sim 25^{\circ} \mathrm{C}$ の範囲では影響な W.

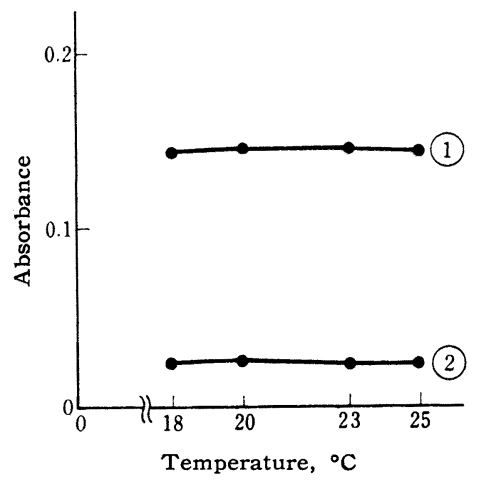

Fig. 2 Effect of temperature on absorbance (1) $\mathrm{Nb}(40 \mu \mathrm{g} / 50 \mathrm{ml})$ (2) $\mathrm{Nb}(0 \mu \mathrm{g} / 50 \mathrm{ml})$

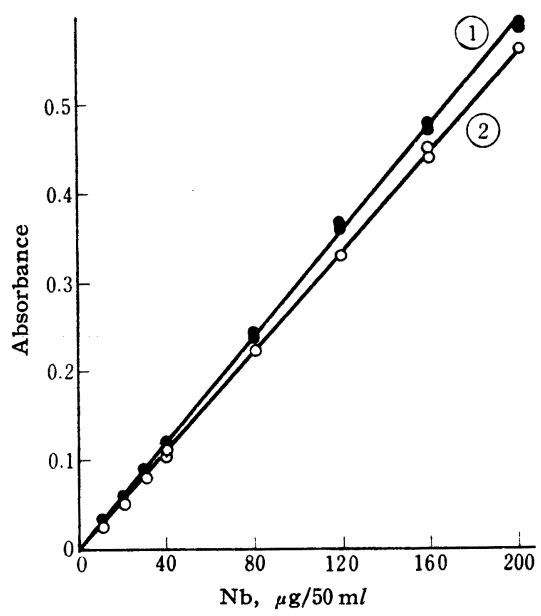

Fig. 3 Calibration curve for $\mathrm{Nb}$ (1) Without separation (2) By the proposed method

Table VII Determination of $\mathrm{Nb}$ in steel with the proposed method

\begin{tabular}{|c|c|c|c|c|c|c|c|c|}
\hline Sample & $\begin{array}{c}\text { Taken } \\
(\mathrm{g})\end{array}$ & $\begin{array}{l}10 \% \text { EDTA } \\
\text { added } \\
(\mathrm{ml} l)\end{array}$ & $\begin{array}{l}\text { Standard } \\
\text { value of } \\
\mathrm{Nb}(\%)\end{array}$ & $\begin{array}{c}\mathrm{Nb} \\
\text { found } \\
(\%)\end{array}$ & \multicolumn{4}{|c|}{ Other elements } \\
\hline B.C.S.277 & 1.0 & 70 & 0.021 & $\begin{array}{l}0.021 \\
0.020\end{array}$ & & & & \\
\hline B.C.S.276 & 1.0 & 70 & 0.055 & $\begin{array}{l}0.053 \\
0.056\end{array}$ & & & & \\
\hline B.C.S.271 & 1.0 & 70 & 0.11 & $\begin{array}{l}0.115 \\
0.114\end{array}$ & & & & \\
\hline N.B.S.101e & 1.0 & 58 & 0.013 & $\left\{\begin{array}{l}0.015 \dagger \\
0.015 \dagger\end{array}\right.$ & $\begin{array}{l}\mathrm{Ni} 9.5 \\
\text { Co } 0.2\end{array}$ & & $\begin{array}{l}\mathrm{Cr} 18 \\
\text { Mo } 0\end{array}$ & $\begin{array}{l}8.0 \\
0.4\end{array}$ \\
\hline N.B.S.153 & $0.5+\left\{\begin{array}{lll}\mathrm{Fe} & 0.5 \mathrm{~g} \\
\mathrm{Nb} & 400 \mathrm{~g}\end{array}\right\}$ & 66 & 0.04 & $\left\{\begin{array}{l}0.041 \dagger \\
0.042 \dagger\end{array}\right.$ & $\begin{array}{ll}\mathrm{Ni} & 0.2 \\
\mathrm{Co} & 4.2\end{array}$ & $\begin{array}{ll}\mathrm{Cr} & 4.2 \\
\mathrm{Mo} & 8.4\end{array}$ & $\begin{array}{ll}\mathrm{V} & 2 \\
\mathrm{~W} & 1\end{array}$ & $\begin{array}{l}2.0 \\
1.6\end{array}$ \\
\hline N.B.S.123B & 0.2 & 16 & 0.75 & $\left\{\begin{array}{l}0.755 \\
0.750\end{array}\right.$ & $\begin{array}{ll}\mathrm{Ni} & 9 \\
\mathbf{W} & 0.2\end{array}$ & $\begin{array}{lr}\mathrm{Cr} & 18.7 \\
\mathrm{Ta} & 0.2\end{array}$ & Mo 0 & 0.2 \\
\hline
\end{tabular}

$+\mathrm{Cr}$ is removed as $\mathrm{CrO}_{2} \mathrm{Cl}_{2}$. Filter : $\mathrm{S} 37$, Cell width $: 10 \mathrm{~mm}$ 


\section{$4 \cdot 4$ 検 7 線}

ニオブ標準溶液 $\mathrm{A}$ 用いて直接発色させ，またニオブ 標準溶液Bを用いて分離操作を行なって（ただし，10\% EDTA 溶液過剩共存量を $3.5 \mathrm{ml}$ にした）作成した検 量線の 1 例を Fig. 3 に示す.

Fig. 3 より明らかなように, 分離操作によりわずかで はあるが低值を示すので，試料分析の際に用いる検量線 は試料と同様に分離操作を行なって作製しなければなら ない.

\section{5 実際試料定量結果}

以上の実験結果を基にして，3の操作法に従って実際 試料を定量した結果，Table VII に示すように十分な 精度をもって定量できた。

本法によれば，チオシアン酸アンモニウムと呈色錯体 を生成するチタン，コバルト，タングステン，モリブデ ンなどの影響がないので，特に特殊鋼については有効で ある・

\section{交献}

1) L. Kidman : Metallurgia, 111, 153 (1961).

2) 石井芳文, 五十崎徳正, 山根照男 : 学振 19 委 7470 (1964).

3) K. L. Cheng : Anal. Chem., 33, 783 (1961).

4) 前川静弥, 米山善夫, 藤森英一 : 本誌, 10, 1335
(1961).

5) H. Freund, A.E. Levitt : Anal. Chem., 23, 1813 (1951).

$$
\hat{w}
$$

Photometric determination of small amounts of niobium in steel using EDTA-beryllium hydroxide separation and thiocyanate method. Ryoichi KageYama, Yoshihide Endo and Toshiyasu Tomori (Technical Research Laboratory, Kawasaki Steel Co., Fukiai-ku, Kobe)

A method for the micro determination of niobium in iron and steels was presented in which iron and other coexisting elements were masked by EDTA, niobium was separated with beryllium hydroxide as a collector, and it was then determined photometrically by ammonium thiocyanate. In the absence of excessive EDTA for the masking of diverse elements, the precipitation of niobium was quantitative, but a definite excess of EDTA was needed to prevent the coprecipitation of titanium, and this caused a slight lowering of the recovery of niobium. (An excess of $3 \mathrm{ml}$ of $10 \%$ EDTA solution masked completely $5 \mathrm{mg} \mathrm{Ti}$, but the recovery of $\mathrm{Nb}$ was $95 \%$.)

The method of separation neverthless has an advantage that $\mathrm{Mo}, \mathrm{W}$, and $\mathrm{Ti}$ are converted to their soluble complexes which do not react to form their colored thiocyanates. This is especially useful in the analysis of special steels containing niobium.

(Received Jan. 26, 1965)

\title{
過酸化水素およびベンジジンによる微量のバナジウムの定量
}

\author{
西田宏*
}

硫酸酸性に打いてベンジジンを過酸化水素で酸化するときバナジウが接触作用を示す.すなわち， バナジウムを含む溶液をとり水で $2 \mathrm{~m} l$ にうすめ, 硫酸 $10 \mathrm{ml}$, 過酸化水素溶液 $(3 \%) 0.50 \mathrm{~m} l$ を加 えて水冷し，てれにベンシシシン溶液 $0.50 \mathrm{ml}$ を加え沸滕水中で加熱すると黄かっ色に発色し，それか らしだいに退色し無色となる．最初の発色は加熱後 4〜5 分で最大となう，バナジムム量が多いはど強 くなる．また，退色の速度はバナジウム量が多いほど大きくなる．そてで，次の二つの定量法を検討し 好結果を得た．（1）一定の色相まで退色する時間を測定して 0.001〜2 $\mu \mathrm{g}$ のバナジウムを定量した.

(2) 溶液を 4〜5 分間沸騰水中で加熱したのち, ただちに室温まで水冷し, $430 \mathrm{~m} \mu$ における吸光度を 測定し $0.002 \sim 0.05 \mu \mathrm{g}$ のバナジウムを定量した.

\section{1 緒言}

硫酸酸性においてジフェニルアミンあるいはジフェニ ルカルバチドを過酸化水素で酸化するとき, バナジウム

* 岩手県工業指導所 : 盛岡市内丸
が接触作用をすることを利用した微量のバナジウムの定 量法はすでに報告した ${ }^{122) . ~}$ 同様に，硫酸酸性において ベンジジンを過酸化水素で酸化するときも゙バナジウムが 接触作用をすることを見いだし，微量のバナジウムの定 量に用い好結果を得た。 